\title{
Personalidade Jurídica e Cidadania Coletiva na Bolívia: Uma Etnografia da Identificação Jurídica e a Formação de Espaços Públicos*
}

Fernanda Wanderley

\section{INTRODUÇÃO}

$\mathrm{U}$ ma das especificidades da formação social boliviana refere-se à coexistência de organizações sociais e territoriais com uma longa tradição histórica, como as comunidades indígenas, as organizações camponesas, as juntas de vizinhos e os sindicatos de trabalhadores. Ao longo de sua história, o Estado reconheceu sujeitos coletivos como interlocutores legítimos e estendeu-lhes direitos cidadãos por meio da mediação de associações. Neste artigo, argumentamos que, durante o período neoliberal na Bolívia, um conjunto de políticas orientadas para a reestruturação do Estado aprofundou a dimensão coletiva de cidadania, processo que, paradoxalmente, não foi acompanhado pela diminuição dos altos níveis de pobreza e desigualdade social.

Durante esse período, não só as lutas e demandas por direitos cidadãos continuaram sendo canalizadas pela via de associações, como também o Estado estendeu direitos civis, políticos e sociais, sobretudo a indivíduos organizados em coletividades, por meio da ampliação da esfera pública estatal. É nesse contexto que se observa que, para amplos seto-

\footnotetext{
* [A tradução do original em espanhol “La Personería Jurídica y la Ciudadanía Colectiva en Bolivia: Una Perspectiva Etnográfica sobre los Documentos de Identificación Jurídica, la Formación de Espacios Públicos y los Significados de Ciudadanía" é de Celia Girard de Peredo.]
}

DADOS - Revista de Ciências Sociais, Rio de Janeiro, Vol. 52, nº3, 2009, pp. 581 a 619. 
res sociais, notadamente para os historicamente excluídos, ser membro da comunidade política nacional fortaleceu solidariedades e lealdades para com outras comunidades intermediárias.

Argumentamos, com base nos resultados empíricos do estudo ${ }^{1}$, que a experiência coletiva de cidadania constitui, de um lado, um status na sociedade boliviana, no sentido de que o Estado outorga um conjunto de direitos (civis, políticos, sociais e coletivos) a indivíduos que fazem parte de coletividades. De outro lado está a formação social de pessoas que se veem e são vistas como membros de grupos e de organizações, e que, a partir dessa participação, recebem o direito de reclamar direitos. Em outras palavras, é como membros de coletividades que muitos indivíduos formulam, demandam, exercem direitos e, consequentemente, se percebem como cidadãos.

Na presente análise, abordamos criticamente um dos principais debates na literatura sobre os direitos civis, políticos e sociais: a irredutibilidade das dimensões individual e coletiva de cidadania. Na concepção individualista, o indivíduo é moralmente anterior à comunidade, e esta importa unicamente porque contribui para o bem-estar dos indivíduos que a constituem. Segundo essa perspectiva, os direitos só podem ser conferidos a indivíduos fora de seus contextos de relações sociais. Temos aqui a definição ontológica do cidadão-indivíduo. Em oposição, os comunitaristas negam que os interesses da comunidade sejam redutíveis aos interesses dos membros que a compõem. Nessa tradição, os indivíduos pertencem, naturalmente, a uma comunidade, definida empírica e até mesmo geograficamente, podendo esta ser unificada por uma única ideia de bem comum. Temos aqui a definição ontológica do cidadão-comunitário.

Como é sugerido por Kymlicka (1996), a maneira como essas duas tradições tratam o assunto dos direitos cidadãos tem como resultado a contraposição das duas dimensões. Em suas palavras,

as teorias sobre os direitos individuais começam por explicar o que é um indivíduo, que interesses tem esse qua indivíduo, e então derivam um conjunto de direitos individuais que protegem esses interesses. De forma similar, os coletivistas começam por explicar o que é uma comunidade, que interesses tem essa qua comunidade, e então derivam um conjunto de direitos comunitários que protegem esses interesses (ibidem:75). 
A discussão avançou propostas em âmbito normativo que matizam posições e desenvolvem vasos comunicantes entre a visão liberal e a comunitária. Kymlicka, por exemplo, abandona o universalismo abstrato da Ilustração e incorpora o reconhecimento da diferença - o particular, o múltiplo e o heterogêneo - do indivíduo concreto. O autor argumenta que a discussão entre individualistas e comunitaristas é irrelevante quando se trata de promover os direitos diferenciados de grupo (proteção externa) nas democracias liberais. Mesmo que essa discussão seja relevante em relação às demandas de restrições internas aquelas que advogam a restrição do direito de os membros dos grupos questionarem e rejeitarem as autoridades e as práticas tradicionais -, estas não são passíveis de defesa nas democracias liberais.

Mouffe (1999) desenvolve uma discussão similar no marco do projeto político de uma democracia plural e radical, e propõe que não se trata de escolher uma tradição em vez de outra na geração de uma nova concepção de cidadania, mas sim de inspirar-se em ambas. Seguindo a autora, o positivo da tradição liberal está na defesa das novidades introduzidas pela democracia moderna, como a defesa do pluralismo, a ideia da liberdade individual, a separação da Igreja do Estado e o desenvolvimento da sociedade civil. Em relação à tradição do republicanismo cívico, o ganho está na introdução do valor da participação pública. O objetivo é superar a dicotomia entre um conjunto de indivíduos sem preocupação pública comum e uma comunidade pré-moderna organizada em torno de uma única ideia substancial de bem comum. Trata-se, então, de recuperar uma vigorosa noção participativa de cidadania, desvalorizada pela tradição liberal, sem sacrificar a liberdade individual.

Essa discussão normativa no campo da filosofia política se entrecruza com o debate metodológico no campo da análise social que orienta as diferentes perspectivas adotadas pelos estudos sobre cidadania. De um lado está o individualismo metodológico, que explica todos os fenômenos sociais pela agregação de decisões de indivíduos racionais, maximizadores e egoístas. Dessa perspectiva, as decisões individuais constituem a base explicativa de qualquer fenômeno coletivo. A partir do coletivismo metodológico, a comunidade, ou sociedade compreendida como um todo orgânico, precede os indivíduos, sendo estes guiados por uma realidade coletiva que minimiza o papel da vontade ou do arbítrio individual (Reis, 1989; Levine, Sober e Wright, 1989). Enquan- 
to o individualismo metodológico concebe o indivíduo subsocializado, o coletivismo metodológico concebe o indivíduo supersocializado.

A perspectiva relacional é uma alternativa entre as duas perspectivas metodológicas ao conceituar a tensão entre os movimentos de individualização e de socialização como constitutiva da vida social. Segundo essa perspectiva, as sociedades modernas caracterizam-se pela diferenciação de esferas sociais, com o consequente posicionamento dos indivíduos em múltiplas relações sociais; portanto, sua identidade constitui-se na interseção desses diversos espaços de sociabilidade. A sociologia relacional nos lembra que as mesmas leis que são a fonte dos direitos cidadãos não se enquadram em nenhum dos extremos entre o individualismo e o coletivismo metodológico².

Somers (1994:79) faz uso de "autonomia em pertencer" (autonomy in membership) e de "liberdade na inclusão" (liberty in embeddedness) para explicar que é o relacionamento de direitos que provê os meios para o exercício de autonomia e de independência na formação dos direitos na sociedade inglesa. Em suas palavras, "os direitos cidadãos foram direitos que supunham um alto grau de independência; simultaneamente, eles pressupunham o pertencimento e os limites de ser membro de um grupo particular - família, comunidade, agremiação sindical, sociedade civil local e esfera pública" (ibidem). Essa perspectiva nos abre a possibilidade de analisar a interdependência das dimensões coletiva e individual na formação da cidadania na Bolívia, e assim evitar tanto as perspectivas essencialistas do indivíduo autossuficiente e independente quanto a idealização da comunidade como um todo orgânico.

A perspectiva relacional permite, portanto, questionar a dicotomia que separa de forma radical os direitos individuais e os direitos de grupo. Como argumentaremos na análise seguinte, a conquista e o exercício individual de direitos civis, políticos e sociais na sociedade boliviana implicaram, e tudo indica que seguirá implicando, o reconhecimento do fato de os indivíduos pertencerem a grupos sociais particulares. Tal reconhecimento, entretanto, traz consigo conteúdos díspares sobre a relação entre indivíduos e grupos sociais, e, consequentemente, sobre os conteúdos das reclamações. De um lado estão as demandas por direitos que somente podem se concretizar pelo reconhecimento das afiliações a comunidades e culturas políticas específicas no seio da comunidade política nacional. De outro, as demandas por direitos que só 
podem se realizar se for mudada a forma de os indivíduos, como mulheres e crianças, pertencerem a comunidades primárias e à sociedade em geral.

A análise que propomos sobre a dimensão coletiva de cidadania não se inscreve na discussão filosófica sobre o tipo de comunidade política a que devemos aspirar. De acordo com as ciências sociais, o estudo está orientado para compreender as formações social e estatal bolivianas em que se forjaram múltiplas dimensões de cidadania. O argumento se desenvolve sobre três pilares: primeiramente, argumentamos que a maneira como o Estado define e simboliza cidadania, e como este estendeu direitos civis, políticos e sociais, não recai nem exclusiva nem principalmente sobre indivíduos sem filiações sociais. Em seguida, analisamos como o exercício e as demandas por direitos pelos setores populares se realizam, sobretudo, pela via associativa. Finalmente, discutimos como as relações entre sujeitos coletivos e Estado se construíram sobre e, por sua vez, reforçaram lealdades e solidariedades para com comunidades intermediárias; portanto, para com identidades sociais que forjam, finalmente, a identidade de cidadãos.

Para abordar e conceituar a cidadania coletiva, partimos da definição de cidadania como relações continuamente negociadas entre indivíduos e coletividades, e as diferentes instâncias estatais (Tilly, 1996; Mische, 1996; Somers, 1994). Cidadania refere-se tanto ao status de membros de uma comunidade política nacional - portanto, aos direitos e obrigações outorgados pelo Estado - quanto à participação em espaços públicos entendidos como espaços participativos, em que atores com múltiplas identidades interagem como um corpo político em negociações e em contestações sobre assuntos públicos e ações estatais.

Distanciamo-nos, assim, dos estudos que definem cidadania unicamente como uma relação jurídica entre os indivíduos e o Estado, em que cada um tem direitos e deveres em virtude de pertencerem à comunidade política nacional. Apesar de os direitos legais outorgados pelo Estado se referirem a uma importante dimensão das relações entre o Estado e a sociedade, essa não é a única. Os processos de reivindicar novos direitos são tão importantes quanto os direitos já outorgados pelo Estado. Do mesmo modo, os direitos que as pessoas exercem na prática, bem como as possibilidades de conversão dos direitos de jure em direitos de facto, definem dimensões igualmente importantes das 
relações entre o Estado e a sociedade e, consequentemente, nas realidades de cidadania.

Por meio da exploração dos efeitos simbólicos e práticos da identificação legal das pessoas como membros da comunidade política nacional e, portanto, como sujeitos de direitos, examinamos a construção social das identidades de cidadania ${ }^{3}$. Em seguida, analisamos as lealdades e solidariedades para com comunidades intermediárias e destas para com a comunidade política nacional. Para isso, dirigimos nossa atenção às instâncias cuja função é outorgar documentos de identidade civil, especificamente a personalidade jurídica e a carteira de identidade. Os encontros entre as repartições de "identificação" e os indivíduos e organizações "identificados pelo Estado" convertem-se em situações privilegiadas para analisar os efeitos simbólicos e práticos da identificação oficial, como sujeitos com ou sem filiações sociais, na vida cotidiana das pessoas. Consideramos que a personalidade jurídica é um documento que adquiriu uma enorme relevância social com as mudanças institucionais dos anos $1990^{4}$, chegando a simbolizar a dimensão coletiva de cidadania na sociedade boliviana. A carteira de identidade, por outro lado, manteve-se como um dos principais símbolos da cidadania individual.

Os documentos oficiais de identificação testemunham o poder do Estado de identificar os atores que qualifica para a posição social de cidadãos e cidadãs, com direitos e obrigações para com ele e para com os outros atores sociais. Os documentos de identificação oficial são, de um lado, os veículos dos direitos outorgados pelo Estado; de outro, símbolos de cidadania. Entretanto, as identificações legais e as definições formais de direitos não devem ser confundidas com as identidades sociais e os significados da população sobre seus direitos e obrigações. O estudo sobre a sociedade boliviana ratifica que os Estados concretos não são entes coerentes que emitem disposições legais sem contradições entre si. Do mesmo modo, as ações e práticas estatais podem produzir efeitos diversos e, muitas vezes, caminhar na contramão sobre os significados de cidadania.

De acordo com a perspectiva teórico-metodológica que articula discursos e práticas, a pesquisa combina a descrição das interações entre os funcionários públicos e as pessoas, no momento em que estas fazem seus documentos de identificação, e entrevistas em profundidade com indivíduos, dirigentes sociais e funcionários. Essas entrevistas permi- 
tiram às pessoas articular suas experiências como cidadãos em espaços públicos, suas percepções sobre o Estado e seus sentimentos de pertencimento a coletividades, incluindo a comunidade política nacional.

A observação das interações concretas nos permitiu distanciarmo-nos das perspectivas abstratas e macrossociológicas de cidadania e, consequentemente, de abordagens que tratam as representações de Estado e sociedade como unidimensionais. Vimos de que maneira, nos encontros com diferentes instâncias do Estado, práticas localizadas e significados de cidadania se articulam, configurando dimensões diferenciadas não só do exercício de direitos como também das representações sociais sobre o significado de ser membro da comunidade política nacional.

O artigo está organizado em cinco partes, além desta introdução e da conclusão. Na primeira parte, revisamos as principais contribuições das ciências sociais bolivianas quanto à longa história de formação de sujeitos coletivos e sua relação com o Estado. A segunda parte está orientada para as mudanças legislativas nos anos 1990 e para os reconhecimentos jurídico e político da pluralidade dos povos e culturas que habitam a Bolívia. Na terceira parte, analisamos os significados simbólico e prático da personalidade jurídica para comunidades indígenas, sindicatos de camponeses, juntas de vizinhos, entre outros grupos sociais. São exploradas as noções de legalidade, direitos, inclusão e participação que se tecem em torno da personalidade jurídica. Na quarta parte, discutimos os efeitos da personalidade jurídica na construção de espaços públicos de participação política e a demanda por direitos dos cidadãos, assim como as continuidades da participação política entre os âmbitos local e nacional, o aprendizado das linguagens estatais e sua articulação com as identidades coletivas. A quinta parte introduz considerações sobre a carteira de identidade como símbolo do cidadão-indivíduo.

\section{A LONGA HISTÓRIA DA FORMAÇÃO DE SUJEITOS COLETIVOS E SUA RELAÇÃO COM O ESTADO}

Antes de analisarmos a formação contemporânea de cidadania, permitimo-nos introduzir resumidamente as principais descobertas das ciências sociais bolivianas no que concerne especificamente à formação histórica dos sujeitos coletivos e à sua relação com o Estado. Esse olhar diacrônico nos permite compreender a ampla interação política e 
social de comunidades indígenas, sindicatos operários e camponeses, corporações empresariais, juntas de vizinhos, associações produtivas, juntas escolares e comitês cívicos regionais ao longo da história da sociedade boliviana, e a formação de uma cultura política na qual se configuram múltiplas dimensões de cidadania.

Em um importante estudo, a socióloga Silvia Rivera (1993) ressalta os efeitos de um evento concreto no período colonial - a recopilação da Lei das Índias, em $1680^{5}$, que estabeleceu juridicamente um reconhecimento relativo, por parte do Estado, do direito de os indígenas se governarem, em seus territórios, por suas próprias autoridades (os mallkus, kuraqas, ou caciques de sangue). Segundo a autora, essa lei contribuiu para a sedimentação da concepção, por parte dos indígenas, de seu próprio território como jurisdição e das "funções" do governo central, que passou a fazer parte da memória coletiva dos aymaras. Em suas palavras,

de acordo com o ponto de vista dos índios, a ideia de "duas repúblicas" que se reconhecem mutuamente, mesmo que permaneçam segregadas espacial e politicamente, chegou a traduzir a complexa visão de seu próprio território, não como um espaço inerte onde se traça a linha de um mapa, mas como jurisdição, ou âmbito de exercício do próprio governo (ibidem:39).

É importante frisar, no entanto, que os reconhecimentos parciais dos territórios indígenas, por parte do Estado (colonial e republicano), sempre estiveram pautados por relações de subordinação e de sujeição dos indígenas.

A historiadora Rossana Barragán (2005) argumenta, com base nos estudos mais recentes sobre a história política dos então nascentes Estados da América Latina, que os processos políticos vividos pela Espanha no século XVIII definiram uma modalidade de organização política que não concebia os indivíduos como os átomos da sociedade, mas a "nação" como constitutiva da sociedade. Esses processos políticos, denominados a via hispânica, influenciaram a emergência dos Estados republicanos na América Latina (Aninno, 1995; López Clavero apud Barragán, 2005). Segundo esses estudos, as experiências espanhola e latino-americana compartilhavam a coexistência de princípios corporativos e liberais de organização social e política. Deve-se sublinhar que, na própria Constituição de Cádiz de 1812, a Espanha é concebida como a reunião de vários territórios, de vários reinos. A própria ideia 
de soberania baseava-se em povos, no plural, em coletividades territoriais e funcionais, antes que em indivíduos. Segundo essa interpretação, a particularidade dos Estados modernos na América Latina não seria resultado da contraposição entre um novo ideário cultural liberal e uma sociedade não moderna, estamental e tradicional.

Seguindo o trabalho de Barragán (2001), os agrupamentos coletivos, incluindo corporações territoriais, funcionais e sociais, continuaram sendo atores centrais no período republicano, em articulação com uma lógica cidadã individual, cimentando as relações entre Estado e sociedade. É no contexto de uma formação social e política, marcada por essa articulação entre uma lógica corporativa e liberal, que se encontra a política das rebeliões e dos pactos, definindo uma das características centrais das relações entre a sociedade e o Estado boliviano. Mediante práticas de enfrentamento, de resistência e, algumas vezes, de subversão da ordem, as corporações territoriais e sociais, incluindo as comunidades indígenas, foram adquirindo reconhecimentos parciais por parte do Estado, ao mesmo tempo que o Estado foi se adaptando às dinâmicas e às diversidades sociais e territoriais. Entretanto, se por um lado os pactos implicaram a criação de espaços relativos de autonomia jurisdicional, por outro, essas organizações nunca deixaram de estar subordinadas à ordem estatal.

Em consonância com essa linha interpretativa, Hylton e Thomson (2003) falam da constituição de uma cultura camponesa e comunitária de insurreição ao longo dos últimos 250 anos. Segundo os autores, a insurreição faz parte de um repertório amplo de recursos políticos comunitários que inclui pactos com o poder estatal, estabelecimento de pleitos jurídicos e a construção de redes inter-regionais de representação política autônoma. Os autores recolhem as experiências de insurreição dos povos indígenas desde os finais da colônia até o ano de 2003, quando a "população majoritária irrompe, ultrapassando os espaços nos quais se mantinha trancada, demonstrando seu poder demográfico e territorial ao reduzir o poder contrário a uma mínima expressão" (ibidem:11). A cultura insurgente fundamenta-se, por um lado, na memória de levantes anteriores e na acumulação de experiência prática pelos que participaram nos processos de luta anteriores e, por outro, em métodos de lutas como a assembleia (cabildo, conselho ou junta), que definem os espaços sociais de deliberação e de tomada de decisão entre as forças mobilizadas, a disciplina social na qual a coerção coletiva garante as obrigações individuais e a tática militar do cerco como medida de 
pressão e de inversão das relações de poder aplicadas ao longo da história contra fazendas, povoados e cidades.

Na obra Historia del Movimiento Obrero Boliviano, Guillermo Lora (1967) reconstrói a incorporação das associações de artesãos nas dinâmicas políticas ao longo da segunda metade do século XIX. Lora argumenta que, durante o governo do presidente Belzú (1848-1855), foi gestado um projeto que procurou consolidar uma base política para os grupos de artesãos, comerciantes e pequenos proprietários urbanos. Foi durante esse governo que se avançou no reconhecimento jurídico, por parte do Estado, das associações de artesãos e de produtores como sujeitos econômicos e políticos. Entretanto, só na primeira metade do século XX é que o movimento operário-artesanal vai se consolidando, sob a influência das ideologias anarquistas e, posteriormente, marxistas. O estudo de Lehm e Rivera (1988) registra esse momento histórico, marcado pela proliferação de organizações gremiais e operárias no âmbito urbano. As autoras relatam os processos de formação organizacional e de dotação de ideologias que fundaram identidades coletivas com capacidade para formular demandas setoriais e interpelar o Estado.

Na primeira metade do século $X X$, o número de organizações operárias, artesanais e camponesas, em círculos cada vez mais ampliados e organicamente estabelecidos, criou um novo cenário social no qual os sindicatos operários e empresariais foram se fortalecendo como atores proeminentes de intermediação da sociedade com o Estado. Em 1936, o presidente David Toro estabeleceu a junção compulsória das associações de produtores rurais e urbanos, em um esforço de consolidação de sua base política por meio da absorção subordinada dos movimentos sociais. Esse projeto não conseguiu consolidar-se em virtude da resistência à cooptação dos movimentos sociais em relação ao Estado.

A Revolução Nacional de 1952 institucionalizou uma forma dual de governo que serviu de referência a práticas que organizaram as relações entre atores coletivos e o Estado nas décadas posteriores. Nos primeiros anos da revolução, um poder estava constituído por milícias operárias e camponesas, reunidas na Central Operária Boliviana $(\mathrm{COB})^{6}$ e outro poder centrava-se no partido do Movimento Nacionalista Revolucionário (MNR), que encabeçava o governo revolucionário. Esses poderes dualistas estabelecem um tipo de institucionalização que acomoda politicamente o movimento popular sem que este ocupe posições políticas dentro do governo. Outras modalidades insti- 
tucionais, como a cogestão política, na qual se combina uma forte representação corporativa com um projeto político-partidário, assim como autogestões parciais de corporações funcionais (universidade) ou espaços territoriais (comunidades indígenas), são recorrentes na história boliviana.

Vemos que a estruturação do poder estatal, durante a segunda metade do século XX, caracterizou-se por formas híbridas de relacionamento com os sindicatos operários e os camponeses, e a institucionalização de um tipo de filiação cidadã coletiva em combinação com a filiação cidadã individual. Pareceria correta a afirmação de que, durante o período de 1952 a 1982, a estrutura sindical foi a principal via de canalização de demandas por direitos civis, políticos e sociais. García Linera (2000) vai mais além e defende que, nesse período, ser cidadão era ser membro de um sindicato. Segundo o autor, "seja no campo, na mina, na fábrica, no comércio ou na atividade artesanal, a maneira de adquirir identidade palpável ante o restante das pessoas e de ser reconhecido como interlocutor válido pelas autoridades governamentais é por meio do sindicato" (ibidem:93).

Sobressai, neste breve relato da história boliviana, que, sob diferentes modalidades, os atores corporativos, especificamente os sindicatos de operários e de camponeses, não só serviram de suporte político para diferentes governos como também influenciaram na construção de modalidades institucionais de organização estatal e de intermediação política $^{7}$. Em face da extensa literatura nessa matéria, surpreende a resistência a redefinir o conceito de cidadania para além da relação não mediada por solidariedades e lealdades entre indivíduos e Estado nacional. Em contraposição à visão unidimensional do conceito de cidadania, alinhamo-nos ao princípio de que esse conceito não pode se manter alheio às condições de sociabilidade que restringem ou possibilitam o exercício de direitos e às categorias com as quais os membros de uma sociedade classificam sua experiência.

\section{NOVOS CONTEXTOS LEGAIS E RECONHECIMENTO JURÍDICO DAS ORGANIZAÇÕES SOCIAIS}

As mudanças na legislação boliviana durante a década de 1990 inauguraram uma nova fase na formação do Estado boliviano, com os reconhecimentos jurídico e político da pluralidade de culturas e povos que habitam o território nacional. Nesse novo ordenamento jurídico do 
Estado, a personalidade jurídica adquiriu um novo significado ao converter-se no documento que reconhece, jurídica e politicamente, as comunidades camponesas, os povos indígenas e as juntas de vizinhos.

Entre as reformas das instituições do Estado e da gestão de políticas sociais a partir de 1993, sobressai a Lei de Participação Popular, que avança em relação à articulação das comunidades indígenas e originárias na vida jurídica, política e econômica do país. As associações comunitárias, como capitanias, ayllus, subcentrais, centrais, federações e outras formas de organização, segundo seus costumes ou disposições estatutárias, são reconhecidas como Organizações Territoriais de Base quando investidas de personalidade jurídica. Após o cumprimento dos requisitos definidos no regulamento da lei, novos espaços formais de participação são abertos em nível municipal, e organizações sociopolíticas que até então se mantinham à margem da ordem estatal têm uma nova via de relacionamento com alguns órgãos públicos.

A modificação na Constituição Política do Estado, em 1994, reconhece a natureza multiétnica e pluricultural da sociedade boliviana em seu art. 1‥ Igualmente, no art. 171 se consagram o reconhecimento, a proteção e o respeito aos direitos sociais, econômicos, culturais, os relativos às Terras Comunitárias de Origem dos povos indígenas e originários, as personalidades jurídicas das comunidades indígenas e originárias, e os procedimentos jurisdicionais comunais.

Com a Lei do Instituto Nacional de Reforma Agrária (Inra), o Estado consolida sua intenção de outorgar o direito coletivo à terra dos povos indígenas e originários. Também define que será a comunidade, segundo seus usos e costumes, que administrará a gestão individual e familiar de recursos naturais renováveis. Veremos, nos testemunhos dos representantes das comunidades, os problemas concretos na consecução do prescrito por essa lei e os procedimentos e táticas para superar essas barreiras.

Nessa linha de reformas se estabelece o novo Procedimento Penal, em 1997, que reconhece a existência de justiça diferenciada e a possibilidade de compatibilizar a aplicação do Direito Consuetudinário Indígena e o Direito Constitucional. Com esse novo mecanismo jurisdicional, procura-se institucionalizar a administração de Justiça Comunitária, garantindo o caráter constitucional de país multiétnico e pluricultural. Essa norma não teve muita difusão e foi sistematicamente ignorada pelo próprio Estado. Outras leis e disposições jurídicas ampliam direi- 
tos e obrigações às diversas organizações sociais de longa tradição no país. Alguns exemplos são as leis de Reforma Educativa, de Municipalidades, de Meio Ambiente, de Hidrocarburantes, Florestal, Tribunal Agrário Nacional, de Maioridade e Capacidade de Trabalhar, os decretos supremos "Conselho Consultivo" e "Línguas Oficiais", a de Agrupaciones Ciudadanas, entre outras.

Quando observamos os últimos 25 anos, encontramos que as ações e práticas estatais foram não só diversas como, muitas vezes, em sentido contrário. Se é certo que as reformas estruturais dos anos 1980 e 1990 se inscreveram em um "projeto político" que restringiu o protagonismo de atores coletivos, como a Central Operária Boliviana, e limitou direitos sociais, como a responsabilidade do Estado na expansão de fontes de trabalho e em sua proteção, também é certo que, nesse mesmo período histórico, o Estado promulgou leis e políticas que impulsionaram o reconhecimento jurídico de outros atores coletivos, como as organizações indígenas e as juntas de vizinhos. Essas ações tiveram o efeito de consolidar as organizações de base como mediadoras de direitos civis, políticos e sociais por meio de sua incorporação sustentada e formalizada em novos espaços públicos estatais.

De fato, os dirigentes de juntas de vizinhos, comunidades indígenas e associações de camponeses que se encontravam em processo de aquisição da personalidade jurídica em novembro de 2005, um mês antes das eleições presidenciais em que Evo Morales saiu vitorioso, indicaram que as mudanças legais da última década promoveram sua incorporação ao espaço público estatal e lhes facultou direitos e benefícios. Essas mudanças são assumidas como o resultado das lutas e demandas que enfrentaram suas organizações, junto com muitas outras, em um longo processo no tempo ${ }^{8}$. Segundo Bienvenido Sacu, dirigente de uma comunidade indígena do leste da Bolívia, para explicar a importância da personalidade jurídica, é necessário fazer um retrospecto dos antecedentes desse documento. Assim, diz ele:

Acontece que durante muitos anos depois da conquista dos espanhóis, da fundação da Bolívia, nossa cultura perdeu-se, desapareceu dentro da legislação boliviana; como povos indígenas, pareceria que não existíramos. Mas acontece que existimos, e graças a esse reencontro de povos, em 1982, começou a primeira etapa de organização. Daí vêm as plataformas de luta, assunto de terras, território, educação, saúde, organização e economia. Então, veio a luta por direitos dos povos indígenas. Depois da marcha por território e dignidade no ano de 1990, o Estado nos 
reconhece dentro da Constituição Política do Estado. Quando falo de dignidade, quero dizer o nosso reconhecimento. A partir daí viemos reivindicando. Posteriormente, elaborou-se um projeto de lei indígena no ano de 1992; recolhemos umas cem assinaturas. Foi então que o Governo vigente nos levou em conta. Não é um presente, e, sim, é uma luta, foi feita uma marcha de mais de 30 dias, desde a cidade de Trinidad até a cidade de La Paz para que nós fôssemos reconhecidos dentro do Estado boliviano. A raiz já foi plantada. Apesar de não ter sido aprovada nossa lei indígena, nos remetemos à reforma constitucional, na qual o art. 1ㅇala que a Bolívia é um país independente, gente soberana, multiétnica, pluricultural. O art. 171 também menciona os direitos dos povos indígenas sobre suas terras comunitárias de origem. Não é por ser bonzinho que nos estão dando esse direito. É fazendo marchas, é preciso gastar os calcanhares, andar até a cidade de La Paz, é luta sacrificada, a marcha, o sol forte, a chuva, o frio, porque lá não é o nosso ambiente. Por isso, deve-se reconhecer a luta dos movimentos indígenas. Foi a partir daí que se aprovou a LPP [Lei de Participação Popular] que menciona que se tem que outorgar personalidade jurídica aos indígenas, camponeses e juntas de vizinhos. É importante que a sociedade nos reconheça, ou que o Estado boliviano nos reconheça com este documento.

As mudanças legais e institucionais durante os anos 1990 são compreendidas como resultado das lutas e demandas empreendidas pelas organizações sociais pelo reconhecimento legal como atores legítimos na comunidade política nacional.

\section{CIDADANIA COLETIVA E PERSONALIDADE JURÍDICA}

Está claro, para muitos dos dirigentes das organizações territoriais de base, que a Lei de Participação Popular e a Lei Inra são as referências de novos direitos e da ampliação do espaço público sob o manto do Estado. Para as juntas de vizinhos, os principais direitos são definidos pela Lei de Participação Popular; uma delas, a junta de Yapacaní, disse-nos que "um bairro tem que ter todos os requisitos para poder reclamar com mais direito e voto, e poder receber mais obras. Então, com personalidade jurídica, temos poder para participar do Orçamento Operativo Anual [Presupuesto Operativo Anual - POA] e também temos direito de reclamar nossas necessidades". Outra junta de vizinhos, da cidade de Cochabamba, explica-nos que a "personalidade jurídica é um requisito mais de um bairro, que de qualquer maneira te- 
mos que ter para que participemos do POA, para que as autoridades nos levem em conta". Essa compreensão está presente em todas as localidades estudadas, tanto no leste quanto no oeste da Bolívia. O dirigente da junta de vizinhos Mirador Atupiris, na cidade de El Alto, relata:

O que consolida uma organização, a Lei 1.541 diz que para ser uma ОТВ [Organização Territorial de Base] deve estar consolidada mediante personalidade jurídica e por isso é tão importante. Quando já dermos entrada nos documentos, temos esse acesso de poder reclamar nossos direitos como OTB, pode ser na administração do departamento, no município, em alguma ONG [Organização Não Governamental]. Mais que tudo, no Orçamento Operativo Anual, se você não tem os documentos lhe dizem que você não é uma organização bem consolidada; inclusive usam o termo "falsificado".

Para as comunidades indígenas, as referências legais dos novos direitos tornam-se mais complexas e combinam a mudança constitucional de 1994, a Lei de Participação Popular e a Lei Inra. Trata-se de demandas de territórios como organização indígena e demandas de inclusão na gestão pública local e no acesso aos recursos destinados aos municípios. Segundo a Central Indígena de Comunidades Originárias de Lomerío, em Santa Cruz,

para demandar uma Terra Comunitária de Origem [TCO], para fazer demandas no território, tem que ter esse documento para ser reconhecida como organização indígena. Era ilegal fazer uma demanda por território até 1996, mas quando foi aprovada a Lei Inra, nós já tínhamos personalidade jurídica e pudemos demandar a TCO. Entretanto, antes que a organização estivesse legalmente constituída, não havia muita atenção por parte do governo municipal.

Segundo as comunidades indígenas do leste da Bolívia (as terras baixas), essas mudanças legais propiciaram a extensão de novos direitos (sobretudo o de território) e novas margens de participação e gestão das comunidades sobre os recursos que existem em suas terras. Essas iniciativas estatais são, para elas, resultado de uma longa luta por reconhecimento, respeito e proteção dos direitos sociais dos povos indígenas e originários.

Para as associações camponesas, a Lei de Participação Popular é vista como um avanço em direção à maior capacidade de participação na 
gestão local e no acesso a recursos públicos para melhorar as condições de vida dos camponeses ou comunitários. Em relação à Lei Inra, para muitos sindicatos de camponeses ela não significou avanços quanto aos direitos sobre o território. Ao contrário, a lei representa uma ameaça à forma sindical de regulação da terra ao limitar o reconhecimento e a garantia somente da propriedade agrária privada e da Terra Comunitária de Origem.

A importância da personalidade jurídica para os sindicatos de trabalhadores assalariados se molda na Lei Geral do Trabalho9. Como nos contou a secretária executiva da Federação Departamental dos Trabalhadores Fabris de La Paz, "quando uma empresa entra em falência, automaticamente a personalidade jurídica dá todo o aval ao sindicato para continuar os trâmites correspondentes em juízo para que se respeitem os direitos dos trabalhadores".

O conjunto dos testemunhos dos dirigentes indica a importância de se adquirir status de organização legal para a consolidação de direitos e o acesso a recursos provenientes do Estado e de outras instâncias não estatais. O dirigente Miguel Ipamo Parapaino, da Central Indígena de Comunidades Originárias de Lomerío, no Departamento de Santa Cruz, indica-nos que "é importante ter status de pessoa jurídica porque uma organização que não nasce de forma legal é como uma criança que, se não tem personalidade jurídica, não pode ter direitos em nível nacional". Esse mesmo dirigente indica que cumprir com todos os requisitos sem intermediar nenhum favor ou procedimento não definido pela lei é importante para que depois esse documento lhes permita ter acesso a todos os direitos e benefícios outorgados por instituições públicas e privadas.

Outro dirigente, de uma junta de vizinhos de Yapacaní, em Santa Cruz, diz que

a personalidade jurídica é como uma ata de reconhecimento, nós já podemos ser reconhecidos em nível nacional, estadual, porque sem a personalidade jurídica é como se uma criança não tivesse certidão de nascimento. É necessário fazer projetos para ficar reconhecidos no município, porque temos mais direito quando temos personalidade jurídica; sem isso é menos o que temos, não temos tanto direito. Com personalidade jurídica é muito melhor. 
Esses testemunhos nos mostram que a dimensão simbólica da personalidade jurídica está estreitamente vinculada à abertura de novos espaços de relacionamento com o Estado, assim como de acesso a recursos públicos e privados que se abrem com as legislações e políticas vigentes no país ${ }^{10}$.

\section{Como, ao Subordinar, o Estado dá Poder a Atores Coletivos}

Os significados que adquire a personalidade jurídica nos permitem observar como, ao subordinar, o Estado dá poder a atores coletivos. Apesar de, em relação aos sujeitos individuais, a subordinação cotidiana à ordem estatal ter o efeito de inferiorização ao limitar a possibilidade de os sujeitos reclamarem seus direitos, como analisamos em outro trabalho ${ }^{11}$, em relação aos sujeitos coletivos o efeito é inverso. É assim que os atos de acatar os requisitos e procedimentos definidos por lei, e aceitar novas designações como o nome de Organizações Territoriais de Base, são acompanhados do posicionamento subjetivo e objetivo dos atores com o poder de protestar, demandar e exercer direitos. $\mathrm{O}$ efeito é o de dar poder aos atores sociais.

A subordinação à ordem estatal se materializa nos próprios procedimentos para tramitar a personalidade jurídica. Como nos explica um dos entrevistados,

para obter a personalidade jurídica, necessitamos ter toda a documentação, o que regula, o que normatiza cada comunidade, como estatuto, regulamento interno, resolução municipal da região, resolução da subprefeitura e personalidade jurídica. E esses são os requisitos indispensáveis da Lei Inra. É com esses procedimentos que conseguimos titulações de terras. Também é com a personalidade jurídica que devemos solicitar o Orçamento Operativo Anual (Comunidade El Guindal, Departamento de La Paz).

A identificação oficial, materializada na personalidade jurídica, também subordina em termos simbólicos. No processo de acatar, gera-se a autoidentificação como organizações consolidadas e, enquanto não obtiver o documento, classificam-se as organizações como "falsificadas". Esses denominativos "falsificados" ou "consolidados" são parte tanto dos discursos de funcionários públicos quanto das pessoas em geral. A afinidade e a coincidência entre os significados legais e morais atribuídos aos documentos oficiais, tanto pelos funcionários públicos quanto pelos membros das organizações, revelam-nos a ascendência 
concreta do Estado (como instância simbólica e prática) sobre organizações que exercem de facto competências estatais em partes do território e em certas dimensões da vida cotidiana de setores sociais. Mesmo que, concretamente, muitas dessas organizações já exerçam funções estatais, reclamam e negociam cotidianamente o reconhecimento de jure de espaços de autonomia para gerenciar esferas da vida cotidiana de suas comunidades (Orellana Hakjyer, 2004).

O empoderamento se dá na formação de atores que reconhecem o espaço aberto por leis e políticas; atores que se apropriam desses canais formais, que negociam e lutam para exercer os direitos definidos pelo Estado e que, além disso, continuam demandando a extensão de novos direitos. Assim expressa o representante de uma comunidade indígena: "São passos que estamos conseguindo, então isso era a personalidade jurídica, depois era outra a demanda da TCO, agora estamos fazendo um plano de gestão territorial, é um passo que nós estamos vendo, conseguindo, como a organização vai avançando, mas sempre com uma base legal" (Comunidade de Lomerío, Departamento de Santa Cruz). Enquanto é forjado um nós, é um nós com direitos que compreendem uma relação de dupla via com o Estado, na qual vão se consolidando gradualmente novos direitos. Nas palavras do mesmo representante: "Se as organizações devem estar constituídas legalmente, isso é responder mais ou menos à exigência da estrutura estatal, o Estado também tem que responder à nossa organização. Este é o tema principal".

Os dirigentes de juntas de vizinhos, comunidades indígenas, associações camponesas e sindicatos compreendem que a personalidade jurídica é a prova de que o Estado os reconhece como sujeitos coletivos, da mesma maneira que a carteira de identidade os reconhece como sujeitos individuais. De fato, a maioria dos dirigentes equipara a personalidade jurídica à certidão de nascimento e à carteira de identidade, equivalência também presente nos discursos dos funcionários públicos. $\mathrm{O}$ dirigente da Central Comunal Urubichá, em Santa Cruz, explica-nos que, "assim como eu tenho minha carteira de identidade que me identifica como fulano de tal e sou um cidadão boliviano, da mesma forma é a personalidade jurídica para as organizações". Os entrevistados interpretam que, como membros de grupos e organizações, eles adquirem um status de cidadãos. Na qualidade de coletividades lhes é reconhecido o direito a participar na gestão local, a ter acesso e a controlar os recursos públicos, e também a reivindicar direitos. 
O dirigente da comunidade de camponeses El Guindal de Ixiamas, no Departamento de La Paz, indica-nos que a personalidade jurídica "permite identificar-nos como comunitários, como cidadãos bolivianos". Explica:

\begin{abstract}
Em nosso país, o que praticam é identificar-nos; como cada cidadão tem sua certidão de nascimento, sua carteira de identidade, então temos também nossas normas, nossas regras em cada comunidade, e é por isso que fizemos nossa personalidade jurídica para adicionar ao trâmite que se chama Título Executorial, para nos titular e, evidentemente, nos identificar - quem somos e de onde viemos, a quem representamos.
\end{abstract}

A personalidade jurídica identifica, simultaneamente, os membros dessa comunidade como comunitários e cidadãos bolivianos. A equidade de ambas as identidades indica a compreensão de que a identificação é dupla: como organização de um determinado tipo e como membro da comunidade política nacional. Observa-se que o efeito simbólico desse documento é a coletivização da identidade.

O reconhecimento das organizações como sujeitos sociais com direitos refaz a base das relações das organizações com o Estado. A personalidade jurídica materializa um reconhecimento em face de outras instâncias, organizações e grupos não estatais. Isso é o que expressa o dirigente de uma junta de vizinhos de Yapacaní, em Santa Cruz: “A personalidade jurídica significa sermos reconhecidos tanto pelo governo quanto pelo povo. Tendo personalidade jurídica, já temos o direito a qualquer reclamação, ninguém pode nos dizer 'vão embora porque não têm personalidade jurídica'".

A identificação de organização legalmente constituída define um novo status não só em relação ao Estado como também em relação a outros atores sociais. Segundo o presidente da Uniarte, uma associação de artesãos indígenas, a personalidade jurídica é a "credencial da organização, nos torna dignos de confiança, que somos responsáveis e sérios para poder empreender gestões". Ele ainda complementa: "Sem esse documento não se é reconhecido legalmente ante a sociedade, ante o Estado e ante qualquer organismo de cooperação". A personalidade jurídica converte-se em um espelho que permite que outros os vejam como sujeitos responsáveis e sérios; é o reflexo do Estado, que solidifica sujeitos que se percebem e são percebidos como agentes idôneos. Não devem passar despercebidas as qualificações morais 
contidas no documento em virtude das implicações sobre os conteúdos de cidadania.

Os sentimentos de dignidade que sobressaem desses testemunhos têm uma correlação direta na formação subjetiva de cidadania. Ser reconhecido pelo Estado e pela sociedade fortalece a autocompreensão como sujeitos portadores do direito de participar no espaço público. $\mathrm{O}$ resultado é a reafirmação de sua condição de atores que podem e devem demandar e exercer direitos. É o que expressa outro dirigente de uma junta de vizinhos de Santa Cruz: "Com isso estamos reconhecidos e temos todo o direito de fazer qualquer reclamação. Direito a participar. Foi uma grande alegria receber a personalidade jurídica". Outra junta de vizinhos, em Cochabamba, relata-nos: "Enquanto tivermos os documentos, teremos esse acesso, poderemos reclamar nossos direitos como organização na prefeitura [equivalente ao estado], município, ONG, embaixadas".

Com o emprego de palavras similares, a maioria dos entrevistados em pleno processo de tramitação de seus documentos estabeleceu uma forte associação entre reconhecimento legal, consolidação das organizações, exercício de direitos e participação na esfera pública. Abel Mamani, então presidente da Federação de Juntas de Vizinhos da Cidade de El Alto (Fejuve), disse que "a personalidade jurídica nos dá validade nesse sentido, nos dá legalidade para que as organizações se consolidem. Quem tem o documento é poderoso".

\section{Cerimônia e Celebração da Personalidade Jurídica}

Os sentimentos de afirmação e conquista associados à personalidade jurídica são expressos nos rituais de entrega do documento que, muitas vezes, se convertem em um grande festejo da organização, com a presença de autoridades oficiais e próprias, assim como convidados de outra vizinhança ou comunidade. Como nos revela o dirigente de uma junta de vizinhos de Cochabamba, "deve-se festejar porque é um desejo, um sonho, por isso festejam com muita alegria". Outro dirigente expressou que "festejamos a personalidade jurídica porque aí está concentrada mais ou menos o que é a existência de nossa organização". Abel Mamani, então presidente da Fejuve, relatou-nos: "É grande ter a personalidade jurídica... É uma festa total, assistimos nós, as autoridades municipais, o governo do departamento, a Igreja, vizinhos de outras zonas". 
O processo de formalização da organização é coadjuvante da consolidação do grupo como coletividade com interesses comuns que conta com recursos jurídicos para participar nos assuntos públicos e defender seus direitos em face do Estado. Um dirigente da Central Operária Regional (COR), da cidade de El Alto, descreve-nos o momento da entrega da personalidade jurídica:

De manhã nos instalamos, cantamos o hino nacional, cumprimentamos as autoridades que estavam ali, o Conselho, os deputados, o governador, o prefeito Quenta e outros mais. Foi magnífico, pois também todos os dirigentes da COR estavam ali para entregar a personalidade jurídica. Já recebemos isso, e o ato estava magnífico para nos satisfazer, pois já temos certidão de nascimento.

O ritual de entrega e/ ou a festa de comemoração convertem-se no momento de tornar real a aquisição de um novo status como membros da comunidade nacional, o qual outorga o direito aos dirigentes que representam a organização de demandar um conjunto de direitos garantidos pelo Estado. Além disso, o reconhecimento oficial ordena as relações entre as organizações sociais ao dirimir possíveis disputas pela autoridade para exercer a representação de setores sociais. Dessa maneira, o Estado produz o efeito de hierarquizar e de consolidar a composição social de organizações territoriais, funcionais e originárias.

\section{FORMAÇÃO DE ESPAÇOS PÚBLICOS}

O conceito de espaço público adotado no presente artigo nutre-se do debate gerado pelos primeiros trabalhos de Habermas $(1962 ; 1974)$. Segundo esse autor, "entendemos por esfera pública todas as instâncias de nossa vida social em que algo que se aproxima da opinião pública pode ser formado. Cidadãos se comportam como um corpo público quando eles discutem de forma irrestrita assuntos de interesse geral" (Habermas, 1974:49; tradução da autora). Seguimos os autores que questionam a ideia proposta por Habermas de que "a esfera privada provê a esfera pública com sujeitos completamente formados, com identidades e capacidades estabelecidas" (Calhoun, 1994:23; tradução da autora). Essa interpretação não considera as práticas participativas e os discursos legais constitutivos da esfera pública e das identidades dos cidadãos (Somers, 1994).

Nessa linha, ressaltamos a definição de espaço público de Somers: 
A esfera pública é concebida como um lugar participativo, no qual os atores, com suas múltiplas identidades como sujeitos legais, cidadãos nacionais, atores econômicos, membros de famílias e comunidades, interagem como um corpo público em negociações e contestações sobre assuntos públicos e a lei nacional. Em meu uso, a esfera pública é um "espaço estruturado" que pode ou não - dependendo da distribuição de poder, capacidades participativas e associativas e culturas políticas populares - ser transformado em uma arena democrática de participação popular e de cultura de contestação (ibidem:74; tradução da autora).

Nesse âmbito, pensamos que os procedimentos de cumprimento dos requisitos da personalidade jurídica dão lugar a interações sociais que promovem a construção de identidades coletivas e espaços públicos. Nessas interações sociais, fortalecem-se as redes de relações sociais, identificam-se objetivos comuns do núcleo grupal, socializam-se noções sobre a localização do grupo em relação a outros atores em espaços mais amplos de interação social, definem-se regras (muitas vezes não escritas) de interação e de sanções dos comportamentos inaceitáveis, formaliza-se a estrutura das organizações e formam-se líderes com familiaridade e segurança para se moverem com os vocabulários e com os procedimentos estatais.

Não menos importante no próprio processo de cumprimento dos requisitos para obtenção da personalidade jurídica é a criação de confiança interpessoal, que passa por interações cotidianas e por eventos extraordinários, como situações nas quais se produzem intercâmbio de critérios, apoios mútuos, socialização de exemplos positivos de cooperação e de experiências bem-sucedidas de solução de conflito e comprovação de respeito de acordos e de tratos. É nas interações diretas que se forjam os princípios de distribuição "justa" de responsabilidades e dos benefícios adquiridos por suas ações conjuntas, assim como os procedimentos para solucionar problemas que constantemente emergem de qualquer forma de cooperação.

Os dirigentes relatam como a formalização das Organizações Territoriais de Base criou uma oportunidade para o fortalecimento das associações. Para muitas juntas de vizinhos, o primeiro passo para tramitar a personalidade jurídica foi a realização de reuniões entre as famílias que habitam um mesmo bairro. Mesmo que muitas juntas de vizinhos já estivessem bem formadas antes do trâmite da personalidade jurídica, para outras esta se transformou na primeira oportunidade para o 
conhecimento de seus vizinhos. Um segundo passo frequente entre essas juntas consistiu na realização de censos de vizinhos para a sistematização das informações mais importantes das famílias, incluindo a situação legal de seu terreno. O consentimento de socializar essa informação e entregar os documentos de propriedade aos dirigentes significou um grande passo no estabelecimento de confiança nos dirigentes e na identificação coletiva de objetivos comuns.

Paralelamente, muitas juntas de vizinhos, assim como comunidades indígenas e sindicatos, promoveram reuniões de capacitação com o apoio da prefeitura, do governo do departamento e de ONGs para o conhecimento de direitos associados à personalidade jurídica. Por meio de reuniões de comunidade e exercícios continuados de redação dos estatutos orgânicos, vão se consolidando espaços de interação nos quais as pessoas vão se orientando como membros de um grupo com interesses comuns, sendo estes de base territorial ou de base funcional. Linguagens e discursos constroem-se com a definição de prioridades, direitos e obrigações de uns para com os outros. A consolidação interna dos grupos se complementa com a compreensão de sua localização em meios sociais e políticos mais amplos e com a elaboração de noções sobre as condições de serem membros da comunidade política nacional.

Esses processos implicam a expansão e a reafirmação do exercício burocrático do Estado por meio da configuração de novas racionalidades. Entretanto, distanciamo-nos das interpretações de que esses processos são unilaterais e unidirecionais. Nancy Postero (2003), por exemplo, afirma que os processos de socialização da Lei de Participação Popular com as comunidades indígenas inculcaram nos líderes indígenas jovens as racionalidades do liberalismo. A autora interpreta as aprendizagens de análise racional da situação em suas comunidades, de proposta de soluções aos problemas diagnosticados, de gerência transparente de suas organizações, de técnicas de contabilidade e relatório financeiro, das responsabilidades nos assuntos comuns de suas comunidades como técnicas de dominação que mostram como todas as políticas implementadas durante a década de 1990 (incluindo as leis de Participação Popular, Inra, Reforma Educativa) apontam para um mesmo objetivo: a interiorização das racionalidades do neoliberalismo. 
Encontramos, ao contrário, que o processo de adequação ao formato estatal é vivido como tomada de poder pelos membros das organizações sociais que se percebem sujeitos de direitos, que dominam os recursos discursivos e organizativos para participar com mais eficácia nos espaços públicos de interlocução com o Estado. O processo é muito mais complexo, o próprio objetivo de mais autonomia para organizar a vida coletiva segundo princípios e valores comunitários requer o trânsito entre esferas de interação mais além de seus "territórios" geográficos e sociais. O domínio das linguagens estatais e a capacidade de interagir com o Estado têm o efeito de fortalecer a demanda de serem "iguais, mesmo que diferentes".

Em outras palavras, o cumprimento dos requisitos definidos pelo Estado contribui para a estruturação mediante a explicitação (oral e escrita) dos princípios que ordenam as práticas vigentes, forçando a formulação de outros que não estavam ainda definidos. O registro escrito das regras de funcionamento da organização é muito valorizado pelos membros, assim como os carimbos, protocolos e resoluções. Observa-se a tentativa de se igualar às práticas estatais na vida cotidiana das organizações; por exemplo, a atualização dos livros de atas em cada nova reunião, andamento e atividade coletiva. Muitas organizações superiores (confederações, federações) exigem até mesmo a personalidade jurídica das novas organizações como requisito para sua afiliação.

\section{Aprendizagem das Linguagens Estatais}

A importância que se outorga às formalidades legais nas organizações sociais é, pelo menos em parte, o resultado das aprendizagens adquiridas nas relações com o Estado. É evidente o forte legalismo nas práticas organizacionais que se expressa na familiaridade com os estatutos, resoluções, regulamentos, livros de atas etc. Mesmo que essa terminologia e as práticas legais sejam um mundo difícil de transitar, este não se torna um mundo inacessível, no qual os dirigentes se sintam irremediavelmente "analfabetos", como interpreta Salman (2004). A possibilidade de mover-se nesse mundo tem implicações significativas nas habilidades de demandar direitos e na disposição para participar no jogo político.

Os dirigentes ressaltam a importância dos processos de aprendizagem das linguagens e dos procedimentos estatais. $\mathrm{O}$ ingresso no mundo da 
legalidade e dos trâmites administrativos requer iniciação para nele transitar com desenvoltura. É na posição de representantes de coletividades que esse mundo se torna mais inteligível e assimilável. Os dirigentes sentem a necessidade de aprender, de saber se movimentar no mundo das terminologias formais, dos procedimentos legais, para poderem representar suas bases no espaço público estatal. Esse conhecimento é adquirido na própria prática, e seu manejo com propriedade é o que define a qualidade do trabalho do dirigente. As aprendizagens também incluem as "manhas", as práticas não escritas, a naturalização da troca de favores que muitas vezes somente beneficiam os dirigentes.

Entretanto, esse conhecimento não se restringe unicamente ao grupo dos dirigentes. Pouco a pouco os membros das organizações vão se familiarizando com os "idiomas", procedimentos e práticas estatais. As "bases" interessam-se por e demandam explicações sobre os procedimentos que em seu nome são realizados. De igual modo, desenvolvem formas de controle e sanção para os dirigentes que violam a confiança depositada a partir da definição de padrões de comportamento correto ou incorreto por parte dos dirigentes.

Diante das dificuldades para a formação de associações, que incluem abusos por parte de dirigentes, uso da representação para benefícios particulares, atos de corrupção, deslealdades, entre tantas outras experiências negativas, as condições que possibilitam a consolidação das associações são ainda mais importantes. Tanto com as experiências negativas quanto com as positivas, o Estado surge como referência central não só na formação discursiva como também nas práticas das organizações ${ }^{12}$.

\section{Continuidades e Descontinuidades da Participação em Assuntos Públicos nos Âmbitos Local e Nacional}

Como vimos nos parágrafos anteriores, o espaço público, entendido como de negociação e de contestação sobre assuntos comuns, constrói-se em interações tanto cotidianas quanto extraordinárias. Na vida diária e no âmbito urbano, destacam-se os bairros em processo de urbanização que ainda não contam com serviços básicos de eletricidade, água e esgoto, além de uma delimitação de zonas consolidada. No âmbito rural, as comunidades indígenas e camponesas providenciaram o espaço de convivência social com graus diferenciados de interdependência com o Estado. 
A organização dos vizinhos para a provisão de bens e serviços públicos redefine um espaço a partir do qual se gesta a "política de cidadania". A identidade cidadã não se limita a compreender-se como usuários de serviços e bens públicos toda vez que se gestam ações coletivas orientadas para a provisão de serviços e bens de maneira concertada com as instituições públicas. Um dirigente na cidade de El Alto explica: "A junta de vizinhos é muito importante: um cidadão que tenha sua casa não pode fazer seu esgoto sozinho; então, a partir do momento em que tenha sua casa, deve fazer parte da junta de vizinhos". A maioria dos entrevistados, dirigentes e membros das juntas de vizinhos ressalta: "A missão de nossa organização é ir melhorando nosso bairro com a reforma de escolas, de postos de saúde, a provisão de serviços básicos (água, esgoto, energia elétrica), a construção de vias públicas, melhoramento e abertura de estradas".

A abertura de espaços de autogestão e de canais concretos de participação na definição dos orçamentos municipais e de controle sobre as decisões das autoridades públicas locais amplia e redefine os sentidos do público e as responsabilidades na política. No âmbito da Lei de Participação Popular, as juntas de vizinhos solicitam a alocação do orçamento municipal para comprar ferramentas e materiais de construção (areia, pedra, cimento). Em contrapartida, os vizinhos entram com a mão de obra para as reformas dos bens públicos. Se antes se solicitavam cotas aos vizinhos para cobrir muitos dos gastos, com a Lei de Participação Popular normatiza-se a alocação de orçamento para prévia planificação das prioridades dos bairros ou comunidades.

Nas comunidades indígenas, uma vez reconhecidas como Terra Comunitária de Origem (TCO), desenvolve-se a gestão do território:

Nossa TCO está bem planificada, cada comunidade tem que fazer sua própria gestão territorial, comunais, o que vai fazer com seus recursos, o que vai fazer com seu solo, onde há madeira, como aproveitar os recursos naturais, porque nós disso vivemos. Mas deve-se aproveitar os recursos de uma forma sustentável [...]. Em termos organizativos, estamos agora uniformizando os nomes das autoridades em nível de comunidade. Antes era presidente, mas isso, reconhecemos que não é nosso; então estamos retomando o que são os caciques, caciques maiores em nível de comunidades, também a estrutura das comunidades, para que haja uma relação direta para fazer as gestões em âmbito territorial [...]. Também estamos vendo os regulamentos de cada comunidade, de como quer cumprir o que está escrito dentro de sua regra de uso e sua 
experiência interna social. Além disso, temos também um regulamento da TCO que recolhe todas as experiências dos regulamentos de todas as comunidades [...]. Planificação é anual (Central Comunal Urubichá, Santa Cruz).

Parece confirmar-se o prognóstico de Rojas (1997:229) de que

o município territorial constitui um espaço de institucionalização democrática com responsabilidades (e não somente de direitos de reivindicação), em que a participação do cidadão não somente é permitida, mas também estimulada pela menor distância deste ao governo local. O fortalecimento do poder local permite ampliar a legitimidade desde a base com intervenção efetiva (planificação participativa, controle social), o que possibilita a governabilidade democrática [...]. Finalmente, aspira a promover uma cultura de concertação, inclusive no âmbito interno do Estado, diferenciando-se do predomínio de "caudilhos" ou homens fortes que definem ao seu arbítrio em suas zonas de influência, que tão frequentemente se associam à cultura política na América Latina.

Por meio da participação direta nos assuntos locais, os sensos de responsabilidade se fortalecem no seio de organizações cujos membros se compreendem como agentes ativos na esfera pública.

A formação de identidades sociais com predisposição para a participação define sociedades articuladas com recursos simbólicos e organizacionais para a intervenção nos assuntos públicos para além do âmbito local. De fato, foi isso que ocorreu com as juntas de vizinhos que, através de suas organizações matrizes, assumiram um papel principal em assuntos concernentes às cidades onde habitam e também nos assuntos de interesse nacional. A mesma observação é válida para as comunidades indígenas. Estas lideraram os movimentos pelo reconhecimento dos direitos coletivos e, especificamente, os direitos ao território que motivaram as mudanças legais dos últimos vinte anos. Foram também as organizações indígenas e camponesas as primeiras a pedir uma Assembleia Constituinte, a qual se concretiza em 2006 sob o governo de Evo Morales.

O grau de organização da sociedade boliviana vem acompanhado da centralidade da política na vida cotidiana dos cidadãos, apesar da tradição elitista das estruturas políticas, da baixa escolaridade da população e dos níveis de pobreza e desigualdade. Parte importante da popu- 
lação não somente mostra um enorme interesse por estar informada sobre a política nacional como também participa em redes e associações que se convertem em espaços estruturados de formação de opiniões sobre os debates políticos. Alguns assuntos sobressaem no interesse da população em geral, como é o caso da propriedade e da gestão dos recursos naturais, os quais se associam às noções de pertencer à comunidade política nacional. Como fruto desse interesse mais além do âmbito local, a Bolívia viveu, nos últimos anos, os eventos conhecidos como a guerra da água em Cochabamba, a guerra do gás, a queda de dois presidentes e a eleição de Evo Morales como presidente constitucional da República.

O trânsito entre a atenção sobre os problemas cotidianos dos bairros e a atenção sobre as políticas econômicas e a propriedade dos recursos naturais nos faz questionar as afinidades e as relações mútuas dos níveis - local e nacional - de "política de cidadania". Uma das afinidades entre esses dois níveis se refere ao fato de que as organizações de base são os espaços nos quais se gestam as interpretações sobre a história do país e do contexto político nacional, a construção de noções sobre os interesses nacionais e os critérios para a avaliação das ações estatais.

Nessas organizações se concretizam os processos de aprendizagem de relacionamento com o Estado, dos canais e as estratégias para conseguir conquistas políticas e de direitos, de maior inclusão na tomada de decisões e de abertura de mecanismos de controle sobre as ações estatais. Esses processos de aprendizagem não são fechados aos membros das organizações e incluem atores externos a elas, como intelectuais, jornalistas e políticos. As interpretações geradas em outras esferas (círculos de intelectuais, meios de comunicação, burocracias não estatais e estatais) circulam e são ressignificadas nesses espaços de interação.

\section{A Multidimensionalidade das Relações entre os Atores Coletivos e o Estado}

Na história recente do país, a diferenciação de táticas de relacionamento com o Estado e a construção de alianças com diversos atores sociais estiveram marcadas pelo grau de abertura ou pelo fechamento de canais de comunicação com os centros de decisão política pública e das oportunidades de influência sobre as políticas. Entre 1985 e 2005, o encerramento dos espaços de decisão das políticas econômicas e a perda de capacidade de representação dos partidos políticos vinculam-se a estratégias de participação por meio de mobilização e pressão nas 
ruas. Simultaneamente, as organizações sociais aproveitaram a abertura de vias de interlocução e de influência nas decisões públicas nos espaços locais. Em outras palavras, com diferentes estratégias e recursos, espaços de participação nos assuntos públicos foram sendo gerados.

A múltipla dimensão das relações entre os atores sociais e o Estado se torna visível quando analisamos a simultaneidade das práticas e estratégias utilizadas pelas organizações sociais para demandar e exercer direitos. Nos discursos dos dirigentes das organizações sociais operárias, sobressai a apropriação daquelas iniciativas estatais que são interpretadas como respostas às suas demandas, que institucionalizam direitos. Simultaneamente, recusam outras iniciativas estatais, interpretadas como retrocessos em seus direitos como cidadãos. $\mathrm{O}$ trânsito entre vias alternativas de participação e influência nas decisões públicas é facilmente acomodado: enquanto aproveitam a abertura de canais de interlocução com o Estado, acionam estratégias coletivas, como a mobilização massiva fora do sistema formal de representação.

A experiência da Central Operária Regional (COR) da cidade de El Alto é exemplar. Essa organização e a Fejuve, da mesma cidade, foram os principais protagonistas do movimento social batizado como a guerra do gás (outubro de 2003), que terminou com a destituição de dois presidentes, Gonzalo Sánchez de Lozada (outubro de 2003) e Carlos Mesa (junho de 2005). Ao mesmo tempo que a Central questionava a legalidade e a legitimidade do Estado, também seguia os trâmites da documentação para obter a personalidade jurídica junto ao próprio Estado que combatia nas ruas ${ }^{13}$.

No ato de entrega de sua personalidade jurídica, no dia 9 de agosto de 2005, Edgar Patana Ticona, máxima autoridade da COR de El Alto, recordou "que foram cinco intensos meses para conseguir a personalidade jurídica" e que foi um dos primeiros passos que ele tinha dado depois de ser eleito secretário executivo. O então presidente da Fejuve El Alto, Abel Mamani, presente no evento, explicou que "é muito importante ter a personalidade jurídica porque dá legalidade às instituições para que se consolidem [...], é de suma importância ter a personalidade jurídica. Quem tem o documento é poderoso".

No evento de "autorização estatal" via concessão de personalidade jurídica, a COR assume uma posição subordinada à ordem estatal; já nos atos de confrontação nas ruas, as organizações assumem posições de 
igual para igual com o Estado. A subordinação é justificada por um dirigente da COR: "O sindicalismo tem que estar baseado no que é a personalidade jurídica. Achamos que é fundamental porque sem essa identidade não podemos fazer nada e também não podemos reclamar nada; simplesmente nos fazem passar por uma organização falsificada". Os discursos de subordinação em que se sublinha que "sem esta identidade não podemos fazer nada nem reclamar nada" certamente se refere a uma das dimensões de relacionamento das organizações sociais com o Estado. Seria uma dimensão mais cotidiana, dentro dos canais formais "das gestões ante as autoridades públicas como o governo central, os governos departamentais, o município", conforme nos indica Abel Mamani.

Os atos de insubordinação nos momentos de confrontação refletem outra dimensão das relações com o Estado. Em 3 de junho de 2005, o jornal La Prensa publicou:

Centenas de vizinhos de El Alto mostraram ontem sua capacidade de pressão como em outubro de 2003. Desde cedo levantaram barricadas, estenderam arames entre os postes de luz, cavaram valas, instalaram postos de vigília, fecharam o Mercado 16 de Julho e prepararam o cerco à instalação de Senkata [armazenadora de hidrocarburante].

Nesses momentos de medição de forças, o Estado surge como o inimigo em uma lógica de guerra em que a sociedade enfrenta o poder estatal. O dirigente da COR nos indica que "nossos inimigos são o governo, a prefeitura, o governo departamental, porque eles não gostam que reclamemos o justo, eles sempre esperam que estejamos calados, braços cruzados $[\ldots]^{\prime \prime}$.

Em ambas as situações, de cumprimentos dos requisitos da personalidade jurídica e de desacato por meio dos enfrentamentos e do controle da vida cotidiana das pessoas e do território mediante bloqueios de ruas e estradas, observa-se o exercício multidimensional de cidadania como demanda de direitos. Nas situações de conflito aberto, os direitos são reclamados à margem de canais institucionais de relacionamento com o Estado, enquanto a obtenção de personalidade jurídica se converte na apropriação das vias e dos mecanismos promovidos pelo Estado para o exercício de direitos. Esse exemplo mostra a coexistência de diferentes espaços de exercício e de demanda de direitos dos cidadãos, o que nos remete aos tecidos complexos e diversos que articulam sociedade e Estado. 
Tanto a participação política por meio dos canais formais abertos pelo Estado quanto a participação fora do sistema político levam a aprendizagens cívicas de comportamento cidadão, o qual se instrumentaliza de diferentes formas, como medição de forças e lutas sociais ou negociação e cogestão. A relação com as instituições públicas para a reivindicação e o exercício de direitos protagonizada por atores coletivos adquirem diversas formas. Em outras palavras, por diferentes vias se forma o público como um conjunto de práticas e atividades em que as pessoas chegam a conceber-se como cidadãos e a assumir a política como um assunto próprio, cristalizando concepções de interesse comum.

\section{CIDADANIA INDIVIDUAL E CARTEIRA DE IDENTIDADE}

Também exploramos neste artigo o significado da carteira de identidade, a qual é descrita pela maioria das pessoas que se encontrava fazendo o documento, em novembro de 2005, como "um documento muito válido", por permitir ultrapassar barreiras, viajar ao exterior, fazer qualquer trâmite, ir ao colégio, entrar para uma repartição pública, entre tantas outras atividades cotidianas. Segundo essas pessoas, a carteira de identidade é o documento que lhes permite exercer direitos civis como o de ir e vir, o direito de controlar bens sem que outros os usurpem (direito de propriedade), estabelecer contratos sustentados pela lei e aceder às instituições de Justiça. As pessoas da terceira idade indicaram que é com a carteira de identidade que podem adquirir o Bonosol, um direito social que entrou em vigência em 1997.

A maioria dos entrevistados expressa que "a carteira de identidade está por cima de tudo", por constituir um requisito para a aquisição de outros documentos, como a carteira de serviço militar, o diploma do segundo grau, o título de eleitor, a personalidade jurídica, entre outros. Compreende-se que a carteira de identidade é parte de uma cadeia de documentos que lhes faculta desenvolver-se cotidianamente sem a intromissão de terceiros, entre eles o Estado. Também são esses os documentos que viabilizam direitos civis, políticos e sociais.

Os efeitos concretos da autorização legal em termos de "permitir" a realização de atividades cotidianas, o estabelecimento de transações, de acesso a bens e serviços públicos e privados posicionam o Estado como uma instância de poder e com poder. É uma das maneiras de o Estado se fazer presente no dia a dia do cidadão. O ato de autorizar, identificar e outorgar direitos e deveres forja "o próprio tecido do mando" ao definir o que as pessoas devem, podem ou não fazer em diferen- 
tes âmbitos de suas vidas. De fato, sem a carteira de identidade elas se veem impossibilitadas de realizar as funções mais triviais, assim como serem beneficiárias por serviços e políticas e, finalmente, de participarem da vida pública.

Além desses efeitos práticos, a carteira de identidade simboliza o fato de pertencer à grande comunidade política. Como nos indica uma das entrevistadas, professora rural de Chimoré, Cochabamba, "a carteira de identidade é um documento que identifica uma pessoa, quem é, de onde é; sem carteira de identidade uma pessoa não é cidadã". Um senhor de Villa Dolores, em El Alto, relata-nos: "A carteira de identidade é sua identificação dentro da sociedade, dentro do governo", é o documento que reconhece sua condição de membro da comunidade política com direitos e, nesse sentido, como um cidadão.

Os documentos oficiais, como a certidão de nascimento, a carteira de identidade e o título de eleitor, transmitem a forte mensagem de que todos os bolivianos e bolivianas são iguais diante do Estado. As eleições, assim como as consultas e os referendos, são importantes eventos que reforçam a mensagem de igualdade de direitos de indivíduos que habitam o território nacional. Outras tantas ações do Estado e da sociedade estão orientadas para a consolidação da ideia de cidadãos-indivíduos portadores de direitos e de obrigações em face do Estado e da sociedade.

É assim que os efeitos simbólicos da carteira de identidade ressaltam a capacidade de o Estado classificar as pessoas como indivíduos e, concomitantemente, como membros da comunidade nacional. Os habitantes de um território são definidos como boliviano, estrangeiro ou boliviano por casamento; habilitado para ser eleitor; dona de casa; bacharel (aquele que terminou o segundo grau) ou profissional; proprietário ou inquilino; casado, solteiro, divorciado ou viúvo. Por meio da identificação materializada em documentos e concretizada em leis, nas decisões de Justiça, nos registros, nos resultados de censos, nas permissões, nos formulários de impostos, entre outros tantos procedimentos, o Estado expressa categorias sobre quem somos, que direitos e obrigações temos uns para com os outros e para com o próprio Estado.

\section{CONCLUSÕES}

Do ponto de vista das ciências sociais, compreendemos a cidadania como processos específicos e historicamente contingentes de reclama- 
ções e de negociações entre o Estado e os atores sociais. A análise orienta-se para a formação de cidadania na sociedade boliviana, na qual a dimensão coletiva se afirma nas lutas, nas demandas e no exercício de direitos, assim como nas modalidades de extensão de direitos a partir do Estado. Uma das especificidades da sociedade boliviana refere-se à sua excepcional capacidade organizativa. A presença de esferas de interação social, ordenadas e controladas por organizações formalmente estruturadas, com uma longa tradição histórica, foi se consolidando e tomando forma com a promulgação de leis e políticas que reconheceram e incorporaram as organizações de base no espaço público, impulsionando a participação de atores coletivos na definição de políticas e na atribuição de recursos públicos.

Analisamos a interação das ações e das práticas estatais, de um lado, e as ações e as práticas dos atores sociais, de outro, na construção de espaços de exercício e de demanda por direitos. As dinâmicas no seio da sociedade civil e a formação de sujeitos que se concebem como membros da comunidade política, e, em consequência, com direitos, condicionam e definem os processos de formação das instituições públicas, a definição de direitos legais e as práticas estatais. Do mesmo modo, as políticas e as práticas estatais formam, de uma ou de outra maneira, os significados de cidadania.

A formação das reivindicações de direitos que se baseiam na autocompreensão de pertencer à comunidade nacional está estreitamente relacionada com os processos de expansão e contração dos direitos institucionalmente outorgados pelo Estado. A história boliviana dos últimos vinte anos indica que ambos os processos, de expansão de uns direitos e de contração de outros, são parte tanto da formação estatal quanto dos espaços públicos onde se gestaram as lutas e as demandas por direitos, seja como sinal de contestação e de resistência, seja como sinal de negociação e de acatamento.

Nesse sentido, as relações entre o Estado e a sociedade boliviana não se deram unicamente como negação, reação ou resistência, nem por parte do Estado, nem por parte dos atores sociais mobilizados. O estudo mostra, ademais, que a composição variada das estratégias de relacionamento das organizações sociais com o Estado não é contraditória. De fato, a apropriação de leis que ampliaram a participação nos assuntos públicos não suprimiu a confrontação em relação a outras leis e políticas públicas compreendidas como retrocessos nos direitos dos cida- 
dãos. Do mesmo modo, as mudanças estatais não podem ser entendidas sem localizá-las nos contextos social e político de formação de espaços públicos, os quais refletem a distribuição relativa do poder na sociedade.

A personalidade jurídica materializa o reconhecimento do Estado de sujeitos coletivos. É como membro de coletividades subnacionais que os indivíduos demandam direitos civis, políticos, sociais e de grupo, como o direito ao território pelas comunidades indígenas. Os direitos outorgados pelo Estado são, por sua vez, reelaborados ao ingressar em redes de significados que reordenam a experiência e definem sentidos de pertencer a coletividades e, portanto, produzem compreensões multidimensionais de cidadania. As representações que se tecem em torno da personalidade jurídica, as quais envolvem noções de legalidade, reconhecimento, direitos, inclusão e participação, tornam visíveis as experiências e práticas concretas que forjam sujeitos coletivos que se percebem aptos a demandar direitos e com poder de participar da vida pública.

(Recebido para publicação em março de 2009)

(Versão definitiva em maio de 2009) 


\section{NOTAS}

1. Realizou-se um total de 148 entrevistas em profundidade com indivíduos, dirigentes sociais e funcionários públicos, e observações das interações em 22 repartições públicas responsáveis por outorgar carteira de identidade e personalidade jurídica nas cidades de La Paz, El Alto, Achacachi, Cochabamba, Chimoré, Santa Cruz e Yapacaní.

2. Para uma análise dos limites do individualismo na teoria dos direitos, consultar López Calera (2000).

3. Entre outros estudos sobre a relação entre documentos e identidade social estão os de Santos $(1979$; 1981) e Peirano (1982). Ambos argumentam que, na sociedade brasileira, a carteira de trabalho é o símbolo de cidadania. Santos ressalta que a cidadania no Brasil não é definida pelos direitos civis, políticos e sociais; desenvolve-se pelo reconhecimento e pela definição por lei das profissões vigentes, por meio de um sistema de estratificação ocupacional. Peirano propõe que a nação brasileira existe como categoria ideológica, mas que é uma nação composta de indivíduos hierarquizados que se diferenciam por sua profissão e pelo lugar que ocupam na sociedade.

4. A longa história da personalidade jurídica articulou-se com novos direitos definidos pela Lei de Participação Popular, promulgada em 1994, e pela Lei do Instituto Nacional de Reforma Agrária, promulgada em 1996, como analisaremos detalhadamente em seguida.

5. Essa lei considerava o mundo colonial dividido em duas entidades: a República de Espanhóis e a República de Índios.

6. As dez agremiações mais importantes no país (mineiros, fabris, gráficos, camponeses, empregados de banco, comércio e indústria) deram origem à entidade máxima dos trabalhadores bolivianos, a COB, em 1953. Ao longo das três décadas seguintes, o sindicalismo, sob a liderança da COB, converteu-se no principal mediador entre a sociedade civil e o Estado. No fim do período 1979-1982, a COB desempenhou um papel central no processo de retorno à democracia.

7. Entre os estudos sobre as formas alternativas de organização social e política à ordem estatal boliviana, ver Murra (1975), Ticona, Rojas e Albó (1995), Platt (1982) e Larson (1988).

8. Durante os anos 1980, período da abertura democrática, as organizações indígenas começaram a fortalecer-se, enquanto as organizações operárias foram perdendo protagonismo político. Nos anos 1990, surge a discussão no interior das organizações indígenas camponesas sobre a identidade originária e a necessidade de recuperar as formas de organização anteriores ao sindicato. Um marco importante nesse período foi a Marcha pela Terra e a Dignidade, em 1990, organizada pelos indígenas do leste (as terras baixas) da Bolívia.

9. A Lei Geral do Trabalho (LGT), promulgada em 1942 e vigente na atualidade, reconhece o direito de associação em sindicatos, que poderão ser patronais, gremiais ou profissionais, mistos ou industriais de empresa, cuja finalidade essencial é a defesa dos interesses coletivos que representa.

10. Entre os autores que avaliaram as reformas políticas e institucionais da década de 1990 como avanços no reconhecimento por parte do Estado da tradição organizativa 


\section{Fernanda Wanderley}

da sociedade boliviana, estão Rojas (1997), Arias e Molina (1997), Medina (1997) e Verdesoto (1997).

11. No trabalho "Práticas Estatais e Cidadania Coletiva e Individual na Bolívia" (Wanderley, 2009), são analisadas comparativamente as interações de funcionários das repartições de identificação e as comunidades indígenas, associações de camponeses, juntas de vizinhos, por um lado, e indivíduos-cidadãos sem afiliações corporativas, por outro. Argumenta-se que as práticas nas repartições de identificação têm o efeito de debilitar a experiência de cidadão-indivíduo e fortalecer a experiência de cidadão-coletivo, principalmente entre os grupos socialmente marginalizados.

12. Sobre as relações entre o sistema político e as organizações sociais, ver os estudos de Quisbert (2003), Ticona, Rojas e Albó (1995) e Ticona (2000).

13. No contexto dos movimentos sociais de 2000-2005, as juntas de vizinhos, os sindicatos de trabalhadores, as comunidades indígenas, entre outras, consolidam-se como atores coletivos "de primeira ordem", ao lado dos sindicatos e das associações camponesas. Foram mobilizações articuladas contra processos de privatização de recursos naturais (especificamente a água), pela consolidação das Terras Comunitárias de Origem, a recuperação do gás e os hidrocarburantes. Mamani Ramírez (2005) argumenta que o levante da cidade de El Alto, em outubro de 2003, estabeleceu microgovernos nos bairros que articularam as estratégias de ação coletiva, conformando espaços de deliberação, de decisões coletivas e aprofundamento de sentidos de identidades entre bairros indígenas e populares, capazes de paralisar a cidade com barricadas. Os dois principais articuladores dessas mobilizações foram a Fejuve e a COR.

\section{REFERÊNCIAS BIBLIOGRÁFICAS}

ANINNO, Antonio (org.). (1995), Historia de las Elecciones en Iberoamérica, Siglo XIX. México, FCE.

ARIAS, Ivan e MOLINA, Sergio. (1997), “La Participación Popular como Fruto de las Luchas Sociales", in MDH-SNPP (orgs.), El Pulso de la Democracia: Participación Ciudadana y Descentralización en Bolivia. Caracas, Nueva Sociedad, pp. 59-77.

BARRAGÁN, Rossana. (2001), El Estado Pactante. Gouvernement et Peuples. La Configuration de l'État et ses Frontières, Bolivie (1825-1880). Tese de doutorado, École des Hautes Études en Sciences Sociales, Paris.

. (2005), “Ciudadanías y Elecciones, Convenciones y Debates". Cuaderno de Futuro, no 21, Informe de Desarrollo Humano, PNUD, pp. 129-222.

CALHOUN, Craig. (1994). "Social Theory and the Politics of Identity", in C. Calhoun (ed.), Social Theory and the Politics of Identity. Oxford, Blackwell, pp. 9-36.

GARCÍA LINERA, Álvaro. (2000), “Ciudadanía y Democracia en Bolivia, 1900-1998”. Revista de Sociología, no 21, pp. 85-100. 
HABERMAS, Jürgen. (1962), The Structural Transformation of the Public Sphere: An Inquiry into a Category of Bourgeois Society. Cambridge, MIT Press.

. (1974), “The Public Sphere". New German Critique, no 3, pp. 49-55.

HYLTON, Forrest e THOMSON, Sinclair. (2003), "Ya es Otro Tiempo el Presente: Cuatro Momentos de Insurgencia Indígena", in F. Hylton et alii (orgs.), Ya es Otro Tiempo el Presente: Cuatro Momentos de Insurgencia Indígena. La Paz, Muela del Diablo Editores, pp. 5-17.

KYMLICKA, Will. (1996), Ciudadanía Multicultural. Barcelona, Paidós.

LARSON, Brooke. (1988), Cochabamba, 1550-1900: Colonialism and Agrarian Transformation in Bolivia. Princeton, Princeton University Press.

LEHM, Zulema e RIVERA, Silvia. (1988), Los Artesanos Libertarios y la Ética del Trabajo. La Paz, Thoa.

LEVINE, Andrew, SOBER, Elliott e WRIGHT, Erik. (1989), “Marxismo e Individualismo Metodológico". Revista Brasileira de Ciências Sociais, no 11, pp. 57-70.

LÓPEZ CALERA, Nicolás. (2000), ¿Hay Derechos Colectivos? Individualidad y Socialidad en la Teoría de los Derechos. Barcelona, Ariel.

LORA, Guillermo. (1967), Historia del Movimiento Obrero Boliviano, 1848-1900. La Paz, Editorial Los Amigos del Libro.

MAMANI RAMÍREZ, Pablo. (2005), Microgobiernos Barriales: Levantamiento de la Ciudad de El Alto (Octubre 2003). El Alto, Cades/Idis-UMSA.

MEDINA, Javier. (1997), “La Participación Popular como Fruto de las Luchas Sociales", in MDH-SNPP (orgs.), El Pulso de la Democracia: Participación Ciudadana y Descentralización en Bolivia. Caracas, Nueva Sociedad, pp. 75-108.

MISCHE, Ann. (1996), "Projecting Democracy: The Formation of Citizenship across Youth Networks in Brazil", in C. Tilly (ed.), Citizenship, Identity and Social History. New York, Cambridge University Press, pp. 131-158.

MOUFFE, Chantal. (1999), El Retorno de lo Político. Comunidad, Ciudadanía, Pluralismo, Democracia Radical. Barcelona, Paidós.

MURRA, John. (1975), Formaciones Económicas y Políticas del Mundo Andino. Lima, Instituto de Estudios Peruanos.

ORELLANA HAKJYER, René. (2004), Interlegalidad y Campos Jurídicos. Discurso y Derecho en la Configuración de Órdenes Semiautónomas en Comunidades Quechuas de Bolivia. Universiteit van Amsterdam/Cochabamba, Huella Editores.

PEIRANO, Mariza. (1982), “Documentos e Identidade Social (Algumas Reflexões sobre Cidadania no Brasil)". Série Antropologia, no 30, UnB, pp. 1-23.

PLATT, Tristan. (1982), Estado Boliviano y Ayllu Andino. Lima, Instituto de Estudios Peruanos.

POSTERO, Nancy. (2003), The Conditions of Democracy: Governmentality and Indigenous Citizenship in Neoliberal Bolivia. Trabalho apresentado na Conferência Sociedade Civil, Desenvolvimento e o Futuro da Democracia na América Latina. La Paz, Centro de Estudios Iberoamericanos y de América Latina. 


\section{Fernanda Wanderley}

QUISBERT, Máximo. (2003), “Fejuve El Alto 1990-1998: Dilemas del Clientelismo Colectivo en un Mercado Político en Expansión". Cuadernos de Investigación Aruwiyiri, no 1, pp. 1-75.

REIS, Elisa Pereira. (1989), "Reflexões sobre o Homo Sociologicus". Revista Brasileira de Ciências Sociais, vol. 4, no 11, pp. 23-33.

RIVERA, Silvia. (1993), "La Raíz: Colonizadores y Colonizados”, in X. Albó e R. Barrios (orgs.), Violencias Encubiertas en Bolivia. Cultura y Política. La Paz, CIPCA-Aruwiyiri, pp. 27-96.

ROJAS, Gonzalo. (1997), "El Rediseño de un Estado (y Sociedad) Pluralista”, in MDH-SNPP (orgs.), El Pulso de la Democracia: Participación Ciudadana y Descentralización en Bolivia. Caracas, Nueva Sociedad, pp. 211-238.

SALMAN, Tom. (2004), "Apocryphal Citizenship: Anthropologizing the Citizenship Debate in Latin America". Journal of Urban History, vol. 30, no 6, pp. 853-873.

SANTOS, Wanderley Guilherme dos. (1979), Cidadania e Justiça: A Política Social na Ordem Brasileira. Rio de Janeiro, Campus.

. (1981), "Reflexões sobre a Questão do Liberalismo: Um Argumento Provisório", in B. Lamounier, F. Weffort e M. V. Benevides (orgs.), Direito, Cidadania e Participação. São Paulo, T.A. Queiroz, pp. 155-188.

SOMERS, Margaret. (1994), "Rights, Relationality, and Membership: Rethinking the Making and Meaning of Citizenship". Law and Social Inquiry, vol. 19, no1, pp. 63-112.

TICONA, Esteban. (2000), Organización y Liderazgo Aymara: La Experiencia Indígena en la Política Boliviana, 1979-1996. La Paz, Universidad de la Cordillera y Agruco.

ROJAS, Gonzalo e ALBÓ, Xavier. (1995), Votos y Wiphalas: Campesinos y Pueblos Originarios en Democracia. La Paz, CIPCA/Fundación Milenio.

TILLY, Charles (ed.). (1996), "Citizenship, Identity and Social History”. International Review of Social History, vol. 40, no 3, pp. 223-236.

VERDESOTO, Luis. (1997), "El Concepto y las Experiencias Regionales de Participación", in MDH-SNPP (orgs.), El Pulso de la Democracia: Participación Ciudadana y Descentralización en Bolivia. Caracas, Nueva Sociedad, pp. 349-380.

WANDERLEY, Fernanda. (2009), “Prácticas Estatales y Ciudadanía Colectiva e Individual en Bolivia". ÍCONOS, Revista de Ciencias Sociales, no 34, pp. 67-79. 


\begin{abstract}
Corporate Entity and Collective Citizenship in Bolivia: An Ethnographic Perspective on Identification Papers and Formation of Public Spaces
\end{abstract}

One of the specificities of the Bolivian social formation is the coexistence of social and territorial organizations with a longstanding historical tradition. The current analysis focuses on the formation of citizenship in Bolivian society, in which the collective dimension is affirmed in the struggles, demands, and exercise of rights, as well as in the various modalities of extension of rights stemming from the state. The current study argues that during the neoliberal period in Bolivia, a series of policies oriented towards restructuring of the state deepened the collective dimension of citizenship as both status and participation, with the certificate of incorporation as the maximum symbolic expression.

Keywords: citizenship; social rights; identification papers; second-generation state reforms; public space; indigenous communities; Bolivia

\title{
RÉSUMÉ
}

Personnalité Juridique et Citoyenneté Collective en Bolivie: Une

Ethnographie de l'Identification Juridique et la Formation d'Espaces Publics

L'une des spécificités de la formation sociale bolivienne est la coexistence d'organisations sociales et territoriales ayant une longue tradition historique. Dans cet article, on examine la formation de la citoyenneté dans la société bolivienne, là où la dimension collective s'affirme dans les luttes, les demandes et l'exercice des droits, ainsi que dans les modalités d'extension des droits accordés par l'État. On affirme ici que, pendant la période néolibérale en Bolivie, un ensemble de politiques orientées vers la restructuration de l'État a approfondi la dimension collective de la citoyenneté comme statut et comme participation, sa plus haute expression symbolique étant le document de la personnalité juridique.

Mots-clé: citoyenneté; droits sociaux; documents d'identification; réformes de seconde génération des états; espace public; communautés indigènes; Bolivie 